\title{
Peertechz
}

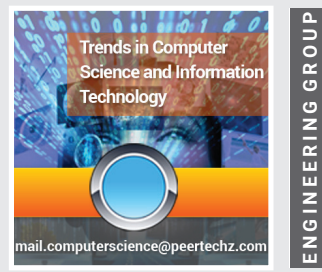

\section{Optimal E-Powertrain}

\section{Solutions for Future Electric}

\section{Vehicles}

\section{ISSN: 2641-3086}

DOI: https://dx.doi.org/10.17352/tcsit

\author{
Erfan Mohagheghi ${ }^{1 *}$, Joan Gubianes Gasso ${ }^{1}$ and $\mathrm{Pu}^{\mathrm{Li}}{ }^{2}$ \\ ${ }^{1}$ MicroFuzzy GmbH, Taunusstraße 38, 80807 Munich, Germany \\ ${ }^{2}$ Department of Process Optimization, IImenau University of Technology, Ilmenau, Germany
}

Received: 29 June, 2020

Accepted: 28 August, 2020

Published: 29 August, 2020

*Corresponding author: Dr. Erfan Mohagheghi, MicroFuzzy GmbH, Taunusstraße 38, 80807 Munich, Germany, E-mail: Erfan.Mohagheghi@microfuzzy.com

https://www.peertechz.com

Check for updates
Owing to increasing emission specification, decreasing price of energy storage systems and power electronic devices, in addition to fast-developing technology, Electric Vehicles (EVs) will become a significant share of automotive market in the near future [1]. Therefore, there is a huge competition among car manufacturers to produce EVs. The final price and driving range are known as vital factors to win the competition. For this purpose, e-powertrain of EVs should be efficiently designed and managed to maximize the driving range $[2,3]$ while the total costs (including implementation, operation, maintenance and replacements) be minimized [4]. A complex multi-objective dynamic Mixed-Integer Nonlinear Programming (MINLP) optimization problem [5-11] needs to be solved to achieve this goal. The major reason of the complexity lies in the hybridization of EVs with different types of power sources [12-17] e.g., Battery Storage Systems (BSSs), Supercapacitors (SCs), Fuel cells (FCs), Photovoltaic (PV) modules, and flywheels (FWs) (Figure 1). BSSs are used

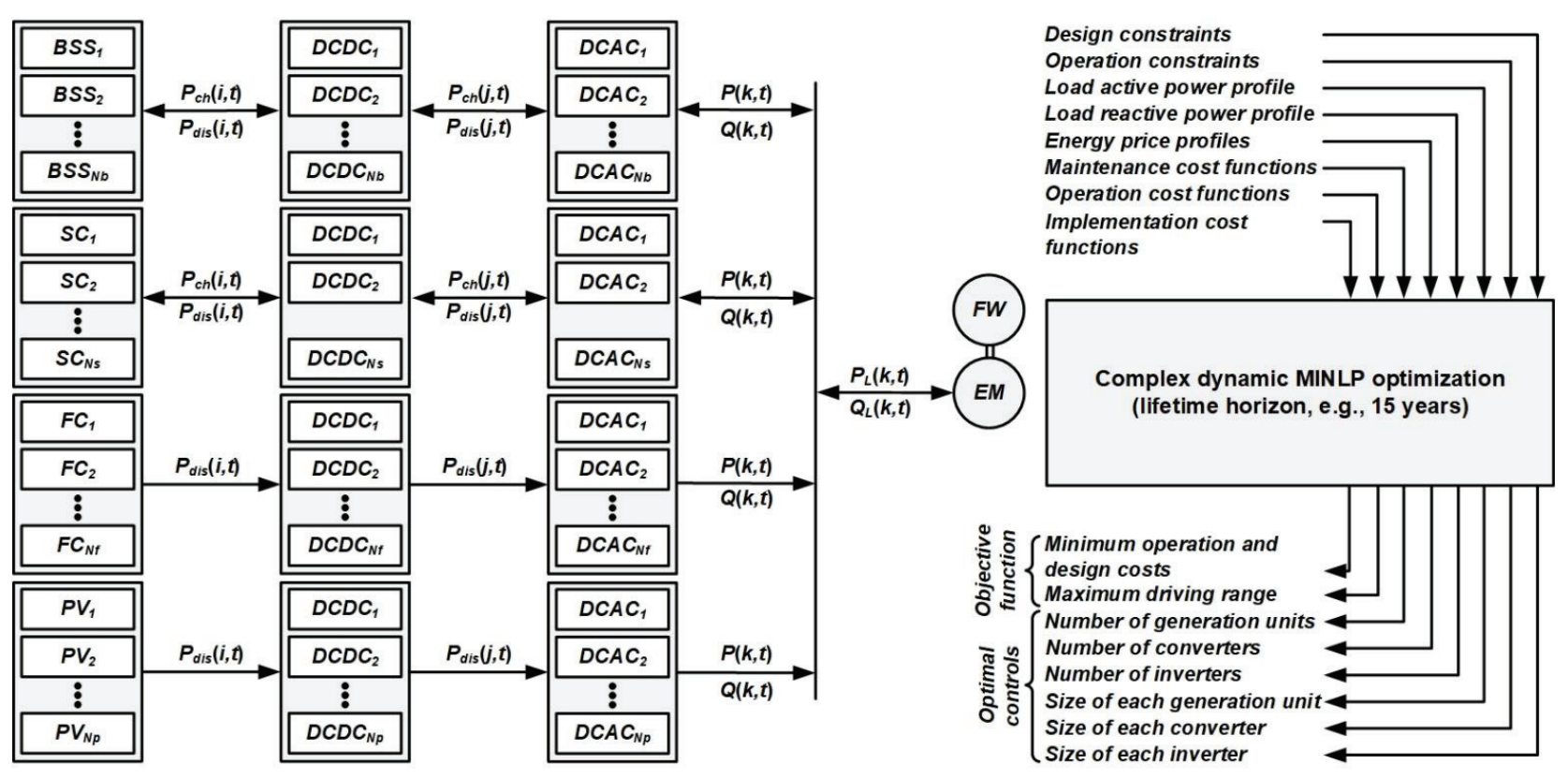

Figure 1: Block diagram of a future e-powertrain and the corresponding dynamic MINLP optimization problem. 
for their high energy density, while FWs and SCs are utilized mostly due to their high power density supplying transient active-reactive power demand. FCs and PV modules work to generate power without exposing pressure to energy grid. As shown in Figure 1, these sources are connected to the Electric Machine (EM) through different DC/DC and DC/AC converters enabling the EM to consume/generate active-reactive power. The efficiency of all these components varies based on their size and load profiles. Therefore, the optimization problem aims to minimize the operation costs (probabilistic) during the lifetime of EV (e.g., 15-year prediction horizon) and the initial costs (deterministic) by finding both the size and the number of all components while satisfying operation and design constraints.

\section{References}

1. Dominković DF, Bačeković I, Pedersen AS, Krajačić G (2018) The future of transportation in sustainable energy systems: Opportunities and barriers in a clean energy transition. Renewable and Sustainable Energy Reviews 82: 1823 1838. Link: https://bit.ly/31GoR3b

2. Thibault L, De Nunzio G, Sciarretta A (2018) A unified approach for electric vehicles range maximization via eco-routing, eco-driving, and energy consumption prediction. IEEE Transactions on Intelligent Vehicles 3: 463-475 Link: https://bit.ly/3lrFd7y

3. Conlon BM, Holmes AG, Tate ED (2011) Range maximization of a hybrid vehicle operating in an electric vehicle operating state. In Google Patents.

4. Li H, Zhou Y, Gualous H, Chaoui H, Boulon L (2020) Optimal Cost Minimization Strategy for Fuel Cell Hybrid Electric Vehicles Based on Decision Making Framework. IEEE Transactions on Industrial Informatics. Link: https://bit.ly/2Qz84IQ

5. Mohagheghi E, Alramlawi M, Gabash A, Li P (2018) A survey of real-time optimal power flow. Energies 11: 3142. Link: https://bit.ly/3hFSZB5

6. Mohagheghi E (2019) Real-Time Optimization of Energy Networks with Battery Storage Systems under Uncertain Wind Power Penetration. Technische Universität IImenau. Link: https://bit.ly/2QyFJm4
7. Mohagheghi E, Alramlawi M, Gabash A, Blaabjerg F, Li P (2020) Real-time active-reactive optimal power flow with flexible operation of battery storage systems. Energies 13: 1697. Link: https://bit.ly/3lrak2S

8. Mohagheghi E, Gabash A, Alramlawi M, Li P (2018) Real-time optimal power flow with reactive power dispatch of wind stations using a reconciliation algorithm. Renewable Energy 126: 509-523. Link: https://bit.ly/34DjxPT

9. Mohagheghi E, Gabash A, Li P (2017) A Framework for Real-Time Optimal Power Flow under Wind Energy Penetration. Energies 10: 535. Link: https://bit.ly/2YHETHM

10. Tawarmalani M, Sahinidis NV (2013) Convexification and global optimization in continuous and mixed-integer nonlinear programming: theory, algorithms, software, and applications. Springer Science \& Business Media 65

11. Alramlawi M, Mohagheghi E, Li P (2019) Predictive active-reactive optima power dispatch in PV-battery-diesel microgrid considering reactive power and battery lifetime costs. Solar Energy 193: 529-544. Link: https://bit.ly/3b5CGLm

12. Fathabadi H (2018) Novel fuel cell/battery/supercapacitor hybrid power source for fuel cell hybrid electric vehicles. Energy 143: 467-477. Link: https://bit.ly/2ECRx42

13. Fu Z, Li Z, Si P, Tao F (2019) A hierarchical energy management strategy for fuel cell/battery/supercapacitor hybrid electric vehicles. International Journal of Hydrogen Energy 44: 22146-22159. Link: https://bit.ly/3gCQ76T

14. Khaligh A, Li Z (2010) Battery, ultracapacitor, fuel cell, and hybrid energy storage systems for electric, hybrid electric, fuel cell, and plug-in hybrid electric vehicles: State of the art. IEEE transactions on Vehicular Technology 59: 2806-2814. Link: https://bit.ly/2DcxyZy

15. García P, Torreglosa JP, Fernández LM, Jurado F (2013) Control strategies for high-power electric vehicles powered by hydrogen fuel cell, battery and supercapacitor. Expert Systems with Applications 40: 4791-4804. Link: https://bit.ly/2EFdhMC

16. Wu Y, Gao H (2006) Optimization of fuel cell and supercapacitor for fuel-cell electric vehicles. IEEE transactions on Vehicular Technology 55: 1748-1755. Link: https://bit.ly/2QwyLOT

17. Fronek PA (1998) Vehicle top solar power generator. In Google Patents.
Discover a bigger Impact and Visibility of your article publication with Peertechz Publications

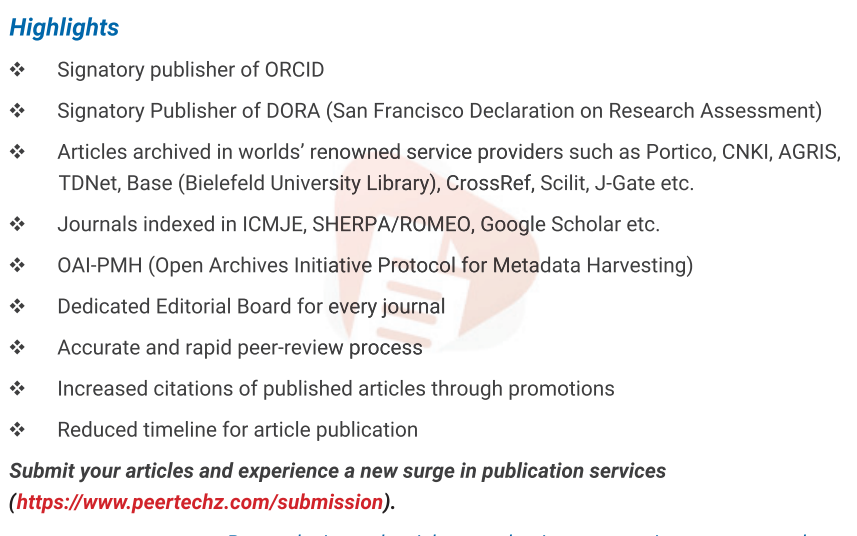

Copyright: @ 2020 Mohagheghi E, et al. This is an open-access article distributed under the terms of the Creative Commons Attribution License, which permits unrestricted use, distribution, and reproduction in any medium, provided the original author and source are credited. 